\title{
Evaluating a Team-Based Learning Method for Detecting Dental Caries in Dental Students
}

\author{
Sang E. Park ${ }^{1, *}$, Junhyck Kim ${ }^{1} \&$ Nina Anderson ${ }^{1}$ \\ ${ }^{1}$ Harvard School of Dental Medicine, Boston, MA, USA \\ *Corresponding author: Harvard School of Dental Medicine, 188 Longwood Avenue, Boston, MA 02115, USA. Tel: \\ 1-617-432-4247. E-mail: sang_park@hsdm.harvard.edu
}

Received: September 5, 2014

Accepted: October 18, $2014 \quad$ Online Published: November 11, 2014

doi:10.5430/jct.v3n2p100

URL: http://dx.doi.org/10.5430/jct.v3n2p100

\begin{abstract}
The purpose of the study was to investigate whether the team-based learning environment facilitated the competency of third year dental students in caries detection and activity assessment. Corresponding data were achieved using digital radiographs to determine the carious lesions in three clinical cases. The distribution of the caries evaluations for each of the 36 students and the 12 teams were tabulated for each mesial and distal surface of each tooth for the three patients. In the first stage of the evaluation, students worked individually for caries assessment. In the second stage, twelve teams of three students each performed the assessment. The teams had a significantly larger percentage of accurate anterior caries evaluations (54\%) than the individual students $(33 \%)\left(X^{2}=5.50 ; \mathrm{p}=.019\right)$, but also saw significantly more carious lesions when there was no lesion (126\%) compared to the students working singly $(85 \%)$ $\left(X^{2}=7.55 ; \mathrm{p}=.006\right)$. The individual students, however, were significantly more likely to incorrectly call incipient caries active $(81 \%)$ than the teams $(14 \%)$.
\end{abstract}

Keywords: team-based learning; dental education; assessment; predoctoral education

\section{Introduction}

Teaching caries detection and diagnosis and subsequent decision for preventive and invasive caries treatment remains as a core topic in dental education. A typical predoctoral curriculum focuses on providing a framework of content and learning objectives for education in cariology; however, teaching reliable detection of carious lesions and especially detecting the earliest signs of the disease is challenging. (Brocklehurst, Ashley, Walsh, \& Tickle, 2012; Lussi, 1993) We envisioned that development of a new and unique teaching method could improve student learning outcomes and ultimately improve the delivery of oral health care.

Since the first inception of team-based learning (TBL) in medical education in 2001 (Seidel \& Richards, 2001; Haidet, O’Malley, \& Richards, 2002), few studies have explored its impact on learning outcomes, particularly in dental education. Team-based learning stimulates an active learning process as small groups of students work together to derive answers to faculty-led questions. (Michaelsen \& Black, 1994) In the TBL structure, students have an opportunity to first work on the questions individually and then in groups to arrive at a consensus decision.

Studies in other health sciences have shown that TBL can be an effective teaching method. TBL in teaching pharmacology revealed that third-year medical students performed as well as fourth-year students in their performance on multiple-choice questions. (Akl, Ghaddar, Sabra, et al, 2012) Levine and colleagues showed that third-year students in psychiatry clerkship trained in TBL demonstrated significantly higher performance on the National Board of Medical Examiners psychiatry subject exam. (Levine, O’Boyle, Haidet, et al, 2004)

TBL's emphasis on peer-to-peer teaching seemed to enhance learning and to suggest that academically weaker students may benefit from this unique teaching methodology. (Nieder, Parmelee, Stolfi, \& Hudes, 2005) Accordingly, we decided to examine learning outcomes from the third year dental students in interproximal radiographic caries detection and activity assessment. The goal of the study was to investigate how easily dental students were able to identify carious lesions using radiographs to detect and assess the depth of interproximal lesions with accuracy, and to determine whether caries detection and activity assessment were facilitated by 
team-based learning methods.

\section{Materials and Methods}

Data was obtained from 36 third year pre-doctoral students. Twelve teams of three persons each were created from which the team caries evaluation data was obtained. The third-year dental students had attended lectures and preclinical training in radiographic caries detection and had limited exposure to comprehensive patient care. Students answered first as individuals, and second as teams of 3 students working together to answer the identical patient cases. Students were each given a computer station with access to axiUm (Exan) and instructed to identify interproximal radiographic caries.

Three separate clinical cases of full-mouth series radiographs were made available, labeled David, Katherine and Michael. The three cases varied in severity and number of carious lesions. The caries evaluations were categorized into five categories (Correct answer; See caries, but there is no caries; Active caries, but called it incipient; Incipient caries, but called it active; Did not see caries, but it was carious). The lesions were visible to the naked eye and verified by two full-time faculty members. In order to standardize the comparisons, the frequencies of the caries categories were then converted into percentages for analyses using nonparametric Chi square tests. Data was analyzed using IBM SPSS statistical software, version 22. Approval for this study was received by the Institutional Review Board at Harvard Medical School and Harvard School of Dental Medicine.

\section{Results}

Data was analyzed using IBM SPSS statistical software, version 22. Students working singly were compared to the three-person teams for their overall distribution of the caries evaluation categories for the three patients combined (Table 1). There was no significant difference between students and teams in the distribution of caries evaluation categories $\left(X^{2}=3.9 ; \mathrm{p}=.424\right)$.

Table 1. Overall Chi Square Students vs. Teams

Caries Evaluation

\begin{tabular}{lllll}
\hline Correct \% & $\begin{array}{l}\text { See caries, but } \\
\text { there is no } \\
\text { caries \% }\end{array}$ & $\begin{array}{l}\text { Active called } \\
\text { incipient \% }\end{array}$ & $\begin{array}{l}\text { Incipient called } \\
\text { active \% }\end{array}$ & $\begin{array}{l}\text { Did not see } \\
\text { caries, but it } \\
\text { was carious \% }\end{array}$ \\
\hline 59 & 48 & 91 & 34 & 61 \\
77 & 40 & 94 & 36 & 52 \\
\hline
\end{tabular}

Considering all three cases together, with regard to the accuracy of identifying caries as either active or incipient, no significant difference was found between the performance of the students $(59 \%)$ and teams $(77 \%)\left(X^{2}=2.38 ; \mathrm{p}\right.$ $=.123$ ). In other words, overall, neither students nor teams outperformed the other in their overall accuracy of assessing caries as active or incipient.

When each of the three patients was considered separately, the distribution of the caries evaluation categories (Table 2 ) were not significantly different between the students and teams $\left(X^{2} s<7.37\right.$; p's $\left.>.117\right)$. Nor were there any significant differences between student and team performance in their accuracy of assessing caries for each patient $\left(X^{2}\right.$ s $<.250$; p's $\left.>.194\right)$. 
Table 2. Chi Square by Patient, Students vs. Teams

\begin{tabular}{lllllllll}
\hline Patient & & Correct $\%$ & $\begin{array}{c}\text { Students vs. } \\
\text { Teams } \\
X^{2} \text { for } \% \\
\text { Correct }\end{array}$ & $\begin{array}{c}\text { See caries, } \\
\text { but there is } \\
\text { no caries } \%\end{array}$ & $\begin{array}{c}\text { Active } \\
\text { called } \\
\text { incipient } \%\end{array}$ & $\begin{array}{c}\text { Incipient } \\
\text { called } \\
\text { active } \%\end{array}$ & $\begin{array}{c}\text { Did not } \\
\text { see caries, } \\
\text { but it was } \\
\text { carious \% }\end{array}$ & $\begin{array}{c}\text { Overall } \\
\text { Distribution } \\
X^{2} \& \mathrm{p} \text { value }\end{array}$ \\
\hline David & Students & 15 & 1.68 & 10 & 36 & 23 & 17 & 7.37 \\
& Teams & 23 & $\mathrm{p}=.194$ & 2 & 39 & 20 & 16 & $\mathrm{p}=.117$ \\
Katherine & Students & 14 & 1.06 & 26 & 19 & 1 & 31 & 4.22 \\
& Teams & 20 & $\mathrm{p}=.303$ & 29 & 21 & 5 & 25 & $\mathrm{p}=.377$ \\
Michael & Students & 30 & .250 & 12 & 36 & 10 & 13 & 0.93 \\
& Teams & 34 & $\mathrm{p}=.617$ & 9 & 34 & 11 & 11 & $\mathrm{p}=.920$ \\
\hline
\end{tabular}

To determine whether the accuracy of the caries evaluations differed between anterior and posterior teeth, responses to individual teeth were combined to create anterior teeth (\# 6-11 and 22-27) and posterior teeth (\# 1-5 and 28-32). When the anterior teeth across the three patients combined were examined (Table 3), the distribution of the caries evaluation categories between students and teams were significantly different $\left(X^{2}=63.11 ; \mathrm{p}<.001\right)$.

Table 3. Chi Square Students vs. Teams for Overall Anterior Teeth

\begin{tabular}{llllll}
\hline & \multicolumn{5}{c}{ Caries Evaluation } \\
\cline { 2 - 6 } & Correct \% & $\begin{array}{l}\text { See caries, but there } \\
\text { is no caries \% }\end{array}$ & $\begin{array}{l}\text { Active called } \\
\text { incipient } \%\end{array}$ & $\begin{array}{l}\text { Incipient called } \\
\text { active \% }\end{array}$ & $\begin{array}{l}\text { Did not see caries, but } \\
\text { it was carious \% }\end{array}$ \\
\hline Students $\mathrm{N}=36$ & 33 & 85 & 55 & 81 & 30 \\
Teams $\mathrm{N}=12$ & 54 & 126 & 69 & 14 & 22 \\
\hline
\end{tabular}

*Totals may be greater than $100 \%$ since percent data was cumulated

The teams had a significantly larger percentage of accurate anterior caries evaluations (54\%) than the individual students $(33 \%)\left(X^{2}=5.50 ; \mathrm{p}=.019\right)$, but also saw significantly more caries when there was no caries $(126 \%)$ compared to the students working singly $(85 \%)\left(X^{2}=7.55 ; \mathrm{p}=.006\right)$. The individual students, however, were significantly more likely to incorrectly call incipient caries active $(81 \%)$ than the teams $(14 \%)$. $\left(X^{2}=47.25 ; \mathrm{p}<.001\right)$.

With regard to the distribution of caries evaluations of the anterior teeth of each patient, the students differed from the teams for only one patient, David (Table 4). The Chi square analyses for David resulted in a significant difference between the students and teams in the distribution of caries evaluation categories $\left(X^{2}=19.22 ; \mathrm{p}<.001\right)$. In terms of percentage correct for caries evaluation for each patient, there were no significant differences between students and teams $\left(X^{2}\right.$ s $\mathrm{s}>3.24$; $\mathrm{p}$ 's $\left.>.072\right)$ for Katherine or David. Patient Michael did not have any incipient or active caries on the anterior teeth, yet $33 \%$ of students and $23 \%$ of the teams "See caries, but there is no caries".

Table 4. Chi Square by Patient Anterior Teeth, Students vs. Teams

\begin{tabular}{llcccccc}
\hline Patient & & Correct \% & $\begin{array}{c}\text { See caries, } \\
\text { but there is } \\
\text { no caries \% }\end{array}$ & $\begin{array}{c}\text { Active } \\
\text { called } \\
\text { incipient } \%\end{array}$ & $\begin{array}{c}\text { Incipient } \\
\text { called } \\
\text { active } \%\end{array}$ & $\begin{array}{c}\text { Did not see } \\
\text { caries, but it was } \\
\text { carious } \%\end{array}$ & $\begin{array}{c}\text { Chi Square } \\
\& \\
\text { p value }\end{array}$ \\
\hline David & Students & 8 & 37 & 31 & 25 & & 19.22 \\
& Teams & 17 & 17 & 41 & 8 & & $\mathrm{p}<.001$ \\
\multirow{2}{*}{ Katherine } & Students & 25 & 7 & 24 & 15 & 30 & 7.79 \\
& Teams & 37 & 8 & 28 & 6 & 22 & $\mathrm{p}=.100$ \\
\multirow{2}{*}{ Michael* } & Students & 0 & 33 & 0 & 0 & 0 & 1.79 \\
& Teams & 0 & 23 & 0 & 0 & 0 & $\mathrm{p}=.181$ \\
\hline
\end{tabular}


* had no active or incipient caries on anterior teeth

With regard to the posterior caries evaluations overall (Table 5), there was no significant difference in the distribution of caries evaluation categories between students and teams $\left(X^{2}=2.48 ; \mathrm{p}=.648\right)$. There was also no significant difference in the percentage of correct posterior caries evaluations between students $(58 \%)$ and the teams $(72 \%)\left(X^{2}=1.51 ; \mathrm{p}=.219\right)$.

Table 5. Chi Square Students vs. Teams for Posterior Teeth

\begin{tabular}{llllll}
\hline & Correct \% & $\begin{array}{l}\text { See caries, but } \\
\text { there is no } \\
\text { caries \% }\end{array}$ & $\begin{array}{l}\text { Active called } \\
\text { incipient } \%\end{array}$ & $\begin{array}{l}\text { Incipient called } \\
\text { active \% }\end{array}$ & $\begin{array}{l}\text { Did not see } \\
\text { caries, but it } \\
\text { was carious \% }\end{array}$ \\
\hline Students N=36 & 58 & 48 & 91 & 38 & 64 \\
Teams N=12 & 72 & 43 & 92 & 37 & 55 \\
\hline
\end{tabular}

With regard to the distribution of caries evaluations of the posterior teeth by each patient (Table 6) no significant differences were found between the students' and teams' distribution of caries evaluation categories $\left(X^{2}\right.$ ' $\mathrm{s}>1.47$; p's $>.435)$. Nor was the percentage correct for students versus teams significantly different for any patient $\left(X^{2}\right.$ 's $<.615 ; \mathrm{p}$ 's $>$.433). (Table 6).

Table 6. Chi Square by Patient Posterior Teeth, Students vs. Teams

\begin{tabular}{cccccccc}
\hline Patient & & $\begin{array}{c}\text { Correct } \\
\%\end{array}$ & $\begin{array}{c}\text { See caries, } \\
\text { but there is } \\
\text { no caries } \%\end{array}$ & $\begin{array}{c}\text { Active } \\
\text { called } \\
\text { incipient } \%\end{array}$ & $\begin{array}{c}\text { Incipient } \\
\text { called } \\
\text { active } \%\end{array}$ & $\begin{array}{c}\text { Did not see } \\
\text { caries, but } \\
\text { it was } \\
\text { carious } \%\end{array}$ & $\begin{array}{c}\text { Chi Square } \\
\& \\
\text { p value }\end{array}$ \\
\hline David & Students & 16 & 5 & 36 & 22 & 20 & 3.79 \\
& Teams & 22 & 1 & 38 & 21 & 18 & $\mathrm{p}=.435$ \\
Katherine & Students & 11 & 33 & 18 & 8 & 31 & 1.87 \\
& Teams & 15 & 35 & 19 & 5 & 26 & $\mathrm{p}=.768$ \\
Michael & Students & 31 & 10 & 37 & 8 & 13 & 1.47 \\
& Teams & 35 & 7 & 35 & 11 & 11 & $\mathrm{p}=.832$ \\
\hline
\end{tabular}

\section{Discussion}

The purpose of the study was to investigate whether a team-based learning environment would facilitate the competency of third year dental students in caries detection and activity assessment. We are not aware of any existing studies which have evaluated the usefulness of TBL in a dental environment.

The average percent correct for teams and students for caries evaluations was $22.7 \%$. Overall, there was no difference between the students versus the teams in the accuracy of categorizing caries as incipient or active. When caries evaluations of anterior teeth were analyzed separately, the teams were more accurate in diagnosing caries in anterior teeth correctly compared to the individual students. Although the teams also had higher percent correct for caries evaluations of posterior teeth than the individual students, there was statistically no significant difference, which may be due to small sample sizes.

Michaelsen and co-investigators have shown that peer influence exhibited through peer teaching by group members and social pressure could assist the weaker student in understanding course materials. (Michaelsen \& Black, 1994) Peer-assisted learning or peer teaching and learning is an effective educational method that promotes a collaborative, self-directed and active learning environment among peers who are students at similar or differing levels of education. (Clarke \& Feltham, 1990; Walker-Bartnick, Berger, \& Kappelman, 1984)

This learning model also encourages students to learn from each other through increased peer-to-peer interactions and team learning in a collaborative learning environment. (Illeris, 2003; McDonald, 2012) Peer tutoring provides an environment for the tutee to learn the material while finding guidance through emotional support and mentorship from peers. (Hum, Maccaro, \& Park, 2014) It can also help the tutors learn the material more in depth while learning 
how to teach and also enjoy the experience. (Haist, Wilson, Brigham, Fosson, \& Blue, 1998; Haist, Wilson, Fosson, \& Brigham, 1997; Barnes, Albanese, Schroeder, \& Reiter, 1978; Buckley \& Zamora, 2007) This aspect of the studies is becoming increasingly important as problem-based learning (PBL) curricula and variations of hybrid curricula are adopted over traditional lecture format curricula. Studies have shown no statistically significant difference in performance of students taught by experts or non-experts of the subject in PBL tutorials. (Park, Susarla, Cox, Da Silva, \& Howell, 2007)

There have been few studies performed to assess whether the team-based learning environment facilitated the competency of third year dental students in caries detection and activity assessment on preclinical exams in a dental school curriculum setting. There were limitations to this study, including the fact that the evaluations were all done on the same day rather than in two sessions separated by a week, in order to determine a measure of intra-student reliability. The students worked as individuals first, then as teams, when alternating teams or single may have reduced the possibility of a systematic bias. The order in which the patients were evaluated was the same and one patient did not have anterior caries, which may have influenced the evaluations.

It is also possible that a student did not agree with the team's assessment, but was outvoted or did not say anything, since this was an exercise, not living patients. While these possible explanations need to be considered, the causes of the discrepancies observed in this pilot study are not entirely clear. Such discrepancies warrant further study and efforts to understand what caused the differences in caries assessment. For instance, one useful method would be to hold post-evaluation calibration sessions, in which the team members can get together and go over their assessments.

It would be useful in the future to obtain a measure of an individual's agreement with the team's evaluation. It is also important to note that such sessions would benefit the students by providing them with an additional learning opportunity to further learn about caries detection. The future direction for further studies involve utilizing team-based learning for both teaching the students in caries detection and calibrating the students to assess them to increase clinical learning.

\section{Conclusion}

The team-based learning methods facilitated correct assessment of caries detection and activity to a degree, as demonstrated by the result that the teams performed better in correct evaluation of anterior teeth compared to the individual students. The team-based learning environment can facilitate the competency of dental students in caries detection and activity assessment and contribute to clinical training in preparation for patient care.

\section{References}

Akl IB., Ghaddar F., \& Sabra R, et al. (2012). Teaching clinical pharmacology using team-based learning: A comparison between third- and fourth-year medical students. Journal of Clinical Pharmacology, 52(12), 1806-1814.

Barnes HB., Albanese M., Schroeder J., \& Reiter S. (1978). Senior medical students teaching the basic skills of history and physical examination. Journal of Medical Education, 53(5), 432-434.

Brocklehurst P., Ashley J., Walsh T., \& Tickle M. (2012). Relative performance of different dental professional groups in screening for occlusal caries. Community Dentistry and Oral Epidemiology, 40, 239-246.

Buckley S., \& Zamora J. (2007). Effects of participation in a cross year peer tutoring programme in clinical examination skills on volunteer tutors' skills and attitudes towards teachers and teaching. BMC Medical Education, 7, 20. http://dx.doi.org/10.1186/1472-6920-7-20

Clarke B., \& Feltham W. (1990). Facilitating peer group teaching within nurse education. Nurse Education Today, 10, 54-57.

Haidet P., O’Malley KJ., \& Richards BF. (2002). An initial experience with team learning in medical education. Academic Medicine, 77, 40-44.

Haist SA., Wilson JF., Brigham NL., Fosson SE., \& Blue AV. (1998). Comparing fourth-year medical students with faculty in the teaching of physical examination skills to first-year students. Academic Medicine, 73(2), 198-200. http://dx.doi.org/10.1097/00001888-199802000-00020

Haist SA., Wilson JF., Fosson SE., \& Brigham NL. (1997). Are fourth-year medical students effective teachers of the physical examination to first-year medical students? Journal of General Internal Medicine, 12(3), 177-181. 
http://dx.doi.org/10.1007/s11606-006-5026-4

Hum L., Maccaro J., \& Park SE. (2014). Cross-year Peer Tutoring in Healthcare and Dental Education: A Review of the Literature. Journal of Curriculum and Teaching, 3(2), 43-57.

Illeris K. (2003). Toward a contemporary and comprehensive theory of learning. International Journal of Lifelong Education, 22(4), 396-406.

Levine RE., O'Boyle M., \& Haidet P, et al. (2004). Transforming a clinical clerkship with team learning. Teaching and Learning in Medicine, 16, 270-275.

Lussi A. (1993). Comparison of different methods for the diagnosis of fissure caries without cavitation. Caries Research, 27, 409-416.

McDonald PL. (2012). Adult learners and blended learning: a phenomenographic study of variation in adult learners' experiences of blended learning in higher education [dissertation]. Washington, DC, George Washington University.

Michaelsen LK., \& Black RH. (1994). Building learning teams: The key to harnessing the power of small groups in higher education. In: Kadel S, Keener J, eds. Collaborative Learning: A Sourcebook for Higher Education. Vol 2. State College: National Center for Teaching, Learning, and Assessment, 65-81.

Nieder GL., Parmelee DX., Stolfi A., \& Hudes PD. (2005). Team-based learning in a medical gross anatomy and embryology course. Clinical Anatomy, 18, 56-63.

Park SE., Susarla SM., Cox CK., Da Silva J., \& Howell TH. (2007). Do tutor expertise and experience influence student performance in a problem-based curriculum? Journal of Dental Education, 71(6), 819-824.

Seidel CL., \& Richards BF. (2001). Application of team learning in a medical physiology course. Academic Medicine, 76, 533-534.

Walker-Bartnick L., Berger J., \& Kappelman M. (1984). A model for peer tutoring in the medical school setting. Journal of Medical Education, 59, 309-315. 